\title{
Optimum Municipal Solid Waste Disposal Site Selection Using Gis Based Multi-Criteria Decision Analysis: A Case of Nekemte Town, Oromia Regional State, Ethiopia
}

\author{
Dula Bekele* Temesgen Eliku \\ Department of Environmental Science, College of Natural and Computational Sciences, Wollega University, \\ P.O. Box 395, Nekemte, Ethiopia
}

\begin{abstract}
Solid waste is a major global concern particularly in developing countries. Municipal landfill site selection is becoming the main challenge as a result of various factors. To make the site to be selected environmentally sound, socially acceptable and economically feasible, GIS based multi-criteria decision analysis (MCDA) method that has the capability to combine spatially referenced data with experts' value judgment was used in this study. The analytic hierarchy process (AHP) was the major technique of MCDA used to derive the weights of the nine criteria considered - distance from road network, geology, distance from fault lines, soil permeability, slope, distance from rivers/streams, distance from lakes, distance from the built-up areas and land use/land cover types. After creating Multiple-ring Buffers for road network, fault lines, rivers/streams, lakes and built-up areas by reviewing various literatures, all the criteria were standardized by reclassifying them into suitability classes. The weights of the reclassified criteria were derived using AHP Pair-wise Comparison Matrix in Microsoft Excel and then combined together using the Weighted Overlay tool in ArcGIS to produce the composite suitability map of the study area. Accordingly, $0.43 \%$ and $0.02 \%$ of the study area are unsuitable and highly suitable, respectively. The remaining $41.64 \%, 51.12 \%$, and $6.8 \%$ of the study area are poorly suitable, moderately suitable and suitable, respectively. The raster composite suitability map of study area was then converted into vector map to select candidate disposal sites. Accordingly, six candidate municipal solid waste disposal sites were selected, evaluated with respect to their area (size), distance from center and distance from the nearby built-up area. They were weighted with respect to these three evaluating criteria using AHP Pair-wise Comparison Matrix and finally mapped and ranked. The first, second and third ranked candidate disposal sites have an area of 46 ha, 29 ha and 35ha, respectively. The first and second candidate sites are located in Burka Jato sub-town, while the third one is located in Sorga sub-town. In order to reduce the adverse impact of surface water pollution in the downstream, runoff should not flow into and out of the MSW disposal sites. To minimize groundwater pollution, detailed investigation on sub-surface condition of the site should be made during design. Greenhouse gases collection should also be designed to reduce air pollution.
\end{abstract}

Keywords: multi-criteria decision analysis; analytic hierarchy process; Pair-wise Comparison Matrix; Weight Overlay

DOI: $10.7176 / \mathrm{JEES} / 10-11-01$

Publication date: November $30^{\text {th }} 2020$

\section{Introduction}

Solid waste is a major global concern particularly in developing countries $[1,2]$. Solid waste management like source reduction, reusing, recycling and resource recovery are the foremost techniques to manage solid waste, nevertheless there is always solid waste left after resource recovery and recycling process for disposal. The need for disposing the solid waste residual in environmental and economical point of view is referred as landfilling [3]. Municipal landfill site selection is becoming the main challenge as a result of refusal of funding by government and non-government organization, population booming in urban areas, impact on health concern shortage of land accessibility and increasing environmental awareness by communities [4].

Selecting landfill site is main difficult jobs to achieve since the site selection process consider various rules and procedures. Moreover taking account environmental factors is another issue as the landfill might have negative impact on the bio-physical environment [5]. Various methods can be used for solid waste landfill site selection [6$8]$.

The output of this method is crucial for identifying suitable site from the total study sites using suitability index, which is essential for ranking the best suitable areas.

Various issues should be integrated for landfill site selection decision and GIS is the dominant one because of the capability of manipulating considerable number of spatial data from different sources. It effectively store, and analyze data in accordance with defined requirement of the user [5]. A combination of GIS and Multi-Criteria Decision Analysis (MCDA) is a powerful tool to resolve the landfill site selection problem, since GIS provide effective handling and display of the data and MCDA deliver reliable ranking of the possible landfill sites on the base of different criteria. 
According to Nekemte town municipality waste management department report (2017), the volume of the municipal solid waste disposed at the final disposal site has been increasing from year to year. For example, it increased from $9,516 \mathrm{~m}^{3}$ in 2008 to $13,330 \mathrm{~m}^{3}$ in 2016. In addition, the existing disposal site waste selected only based on the distance from the main road. Other important environmental, social criteria were not considered. Hence, appropriate waste disposal site which is environmentally sound, socially acceptable and economically affordable should be selected. The objective of this study is to select sites for an appropriate landfill area of Nekemte Town using the integration of Geographic Information Systems (GIS) and Multi-criteria Decision Analysis (MCDA).

\section{Study Area}

Nekemte town, which was established as a town of municipality in 1942 , is located between $9^{\circ} 3{ }^{\prime} 22^{\prime}{ }^{\prime}-9^{\circ} 6^{\prime} 27^{\prime}$ ' North latitude and $36^{\circ} 30^{\prime} 31^{\prime \prime}-36^{\circ} 35^{\prime} 11^{\prime \prime}$ 'east longitude with an average altitude of $2,115 \mathrm{~m}$ above sea level. The town has a total area of about $53.8 \mathrm{~km}^{2}$ with a total population of over 122,000. Currently, it is divided into seven administrative sub-towns: Bake Jama, Kaso, Bakanisa-Kase, Chalalaki, Burka Jato, Darge and Sorga.

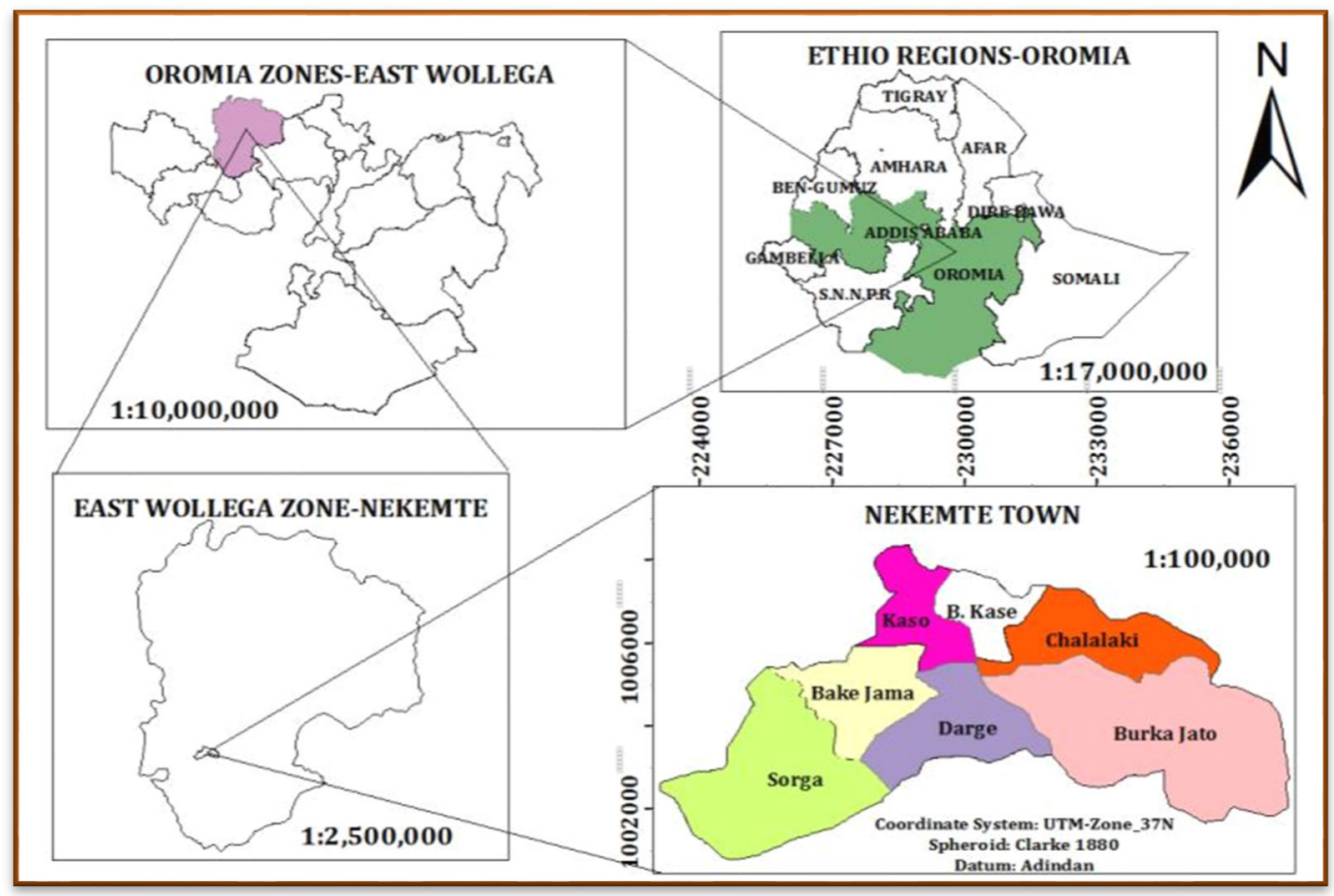

Figure 1 : Location map of the study area

\section{Materials and Methods}

Data identified and collected on the socio-economic and environmental criteria identified were land use/land cover types, distance from the built-up areas, distance from rivers/streams, distance from lakes, soil permeability, slope, distance from road network, distance from fault lines, and geology.

The land use/land cover data of the study area was prepared by merging the land use/land cover shape-file prepared by the municipality and land use/land cover shape file of the study area prepared from Landsat 8 image of the study area. The roads network and built-up shape-file of the study area was obtained from the LU/LC shapefile of municipality. The shape-file of rivers/streams was derived from the DEM of the study area. The soil shapefile was acquired by clipping from the Didesa Basin soil shape-file prepared by [9]. And finally, the geologic and faults shape- file of the study area was obtained by digitizing the geologic map of Nekemte area prepared by Geological Survey of Ethiopia [10]. Hand held etrex 10 GPS was used to collect ground control points of the existing waste disposal site, residences and school nearby the existing waste disposal site, rivers/streams nearby the existing waste disposal site, and center of the study area (location of the municipality).

\section{Methodology}

After geo-referencing to UTM_Zone_37N coordinate system and Adindan datum, all the datasets were reclassified by giving new values to generate standardized input thematic maps. GIS based multi-criteria decision analysis for municipal solid waste disposal site selection was employed in two steps. In the first step, GIS was used to identify unsuitable sites based on the established criteria mentioned before. Each criterion was categorized into five suitability classes: highly suitable, suitable, moderately suitable, poorly suitable and unsuitable (restricted) with 
ranks from 5 to 1, respectively. After reclassifying all the thematic maps, the weight of each criterion was derived using Analytic Hierarchy Process (AHP) which is based on experts' value judgments in comparing the classes and preparing the numerical matrices in Microsoft Excel.

That is, in the first step, each criterion was weighed based on the minimum and maximum buffer distances and/ or suitability requirements. As a result, the criteria were standardized through reclassification and their thematic maps were generated. In the second step, the significance of each criterion relative to the remaining criteria for municipal solid waste selection was expressed by giving weights. AHP weight derivation method using Microsoft Excel was used to compare two criteria at a time based on the expert judgment and a pair-wise comparison matrix from which a set of weights called Eigenvectors along with consistency ratios were produced for each of the criteria being considered. After giving external weights to each thematic layer, Weighted Overlay technique was used to generate the overall suitability map that combined all the weighed layers.

After creating the final suitability map through the Weighted Overlay tool in ArcGIS 10.2, the AHP process was again employed in order to compare the alternative potential disposal sites with one another with respect to their size, their distance from the center of the town, and their distance from the nearby built-up areas so as to choose the most suitable among the alternative potential disposal sites. Finally, field check was undertaken to verify the suitability of those potential disposal sites according to the evaluating criteria.

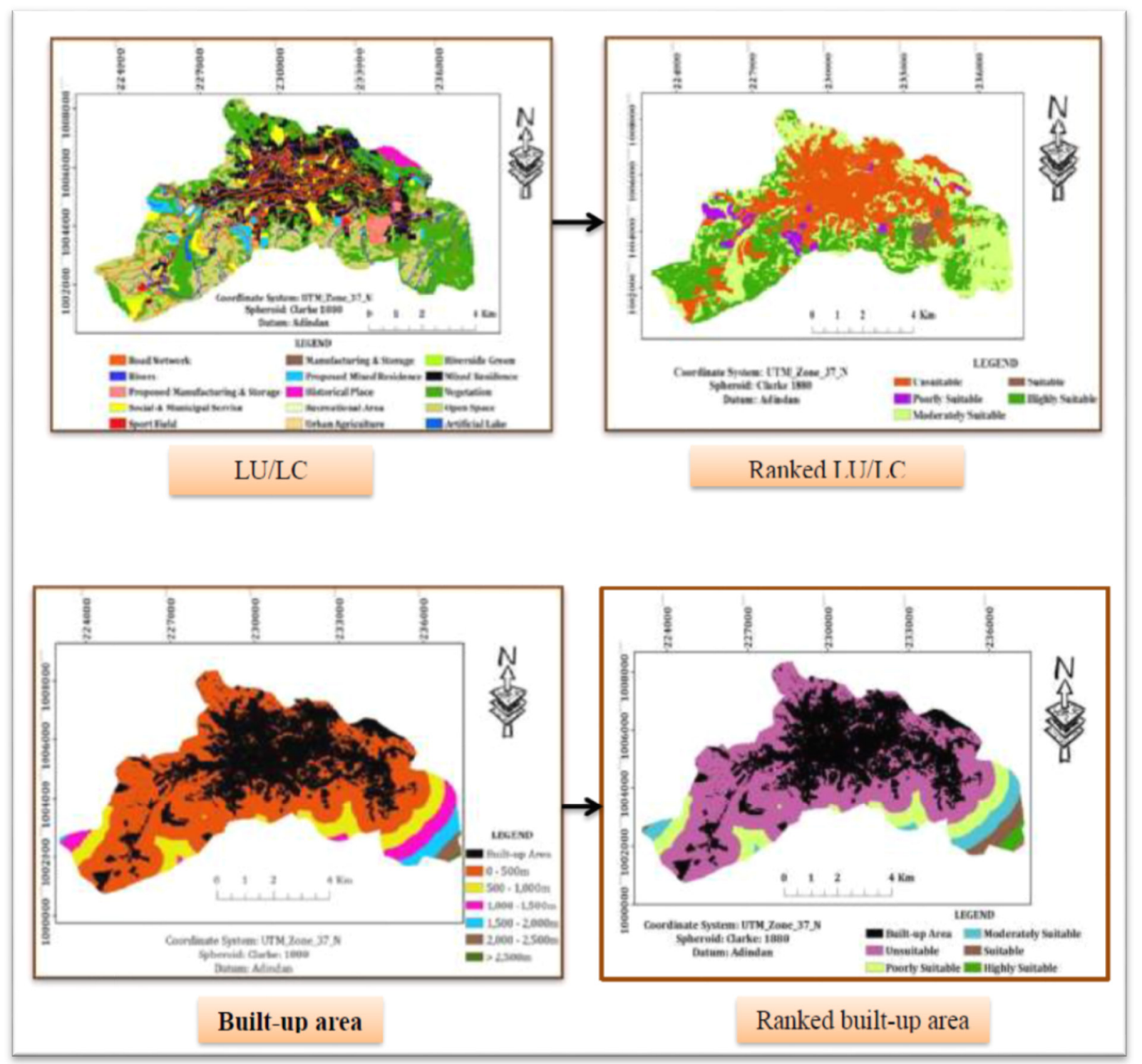

Figure 2: Original and reclassified thematic maps 


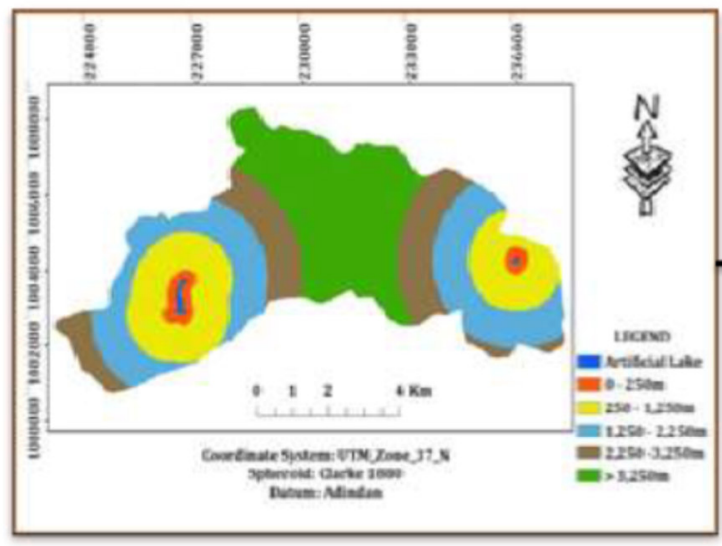

Lakes buffer

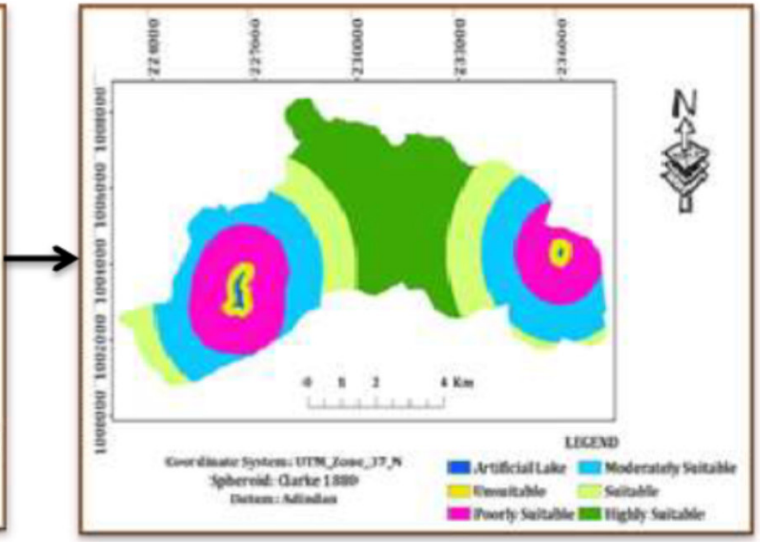

Ranked lakes buffer

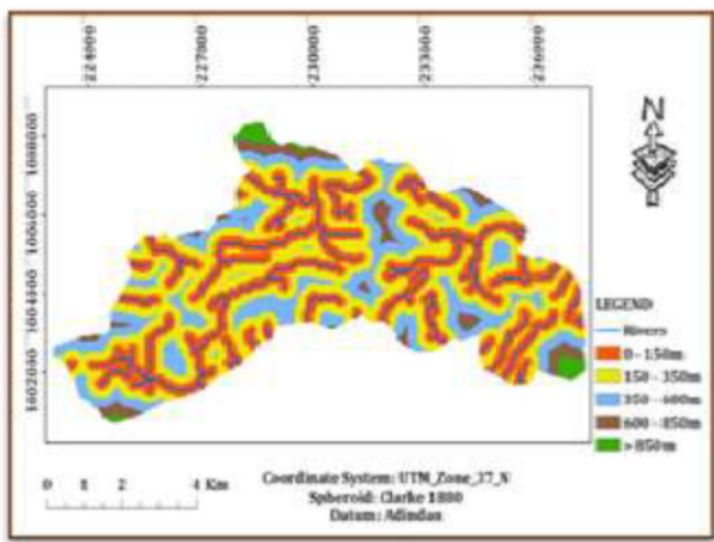

Rivers/Streams buffer

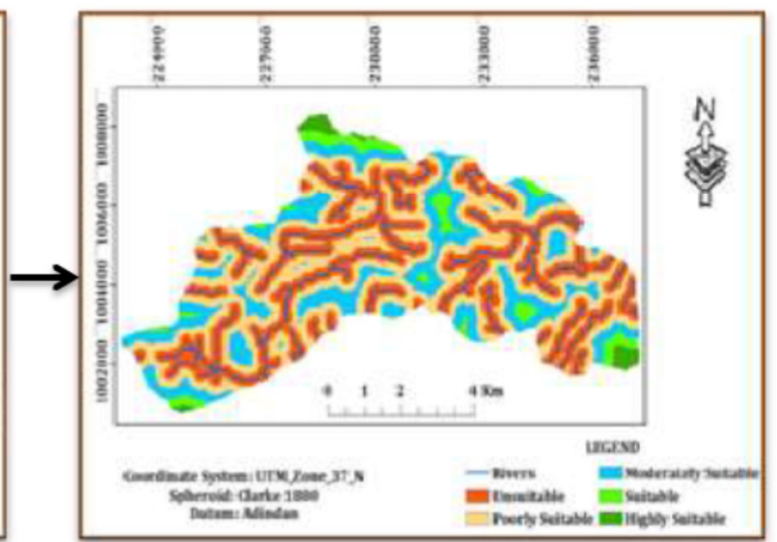

Ranked Rivers/Streams buffer

Figure 3: Original and reclassified thematic maps 


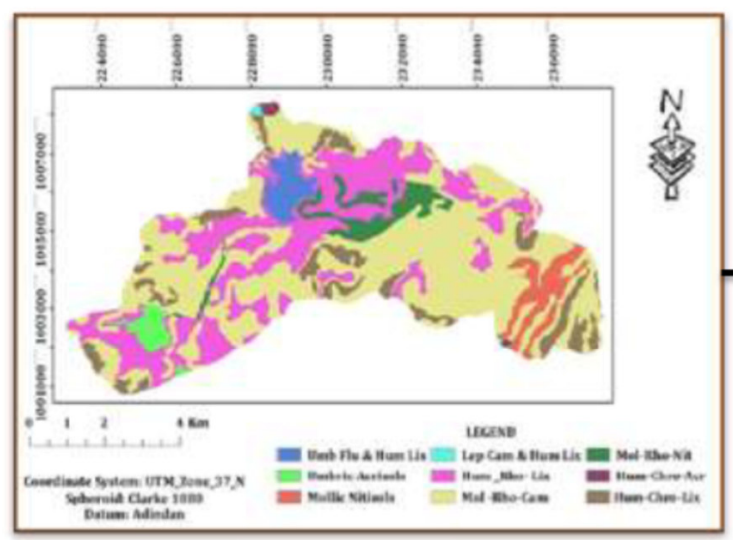

Soil types

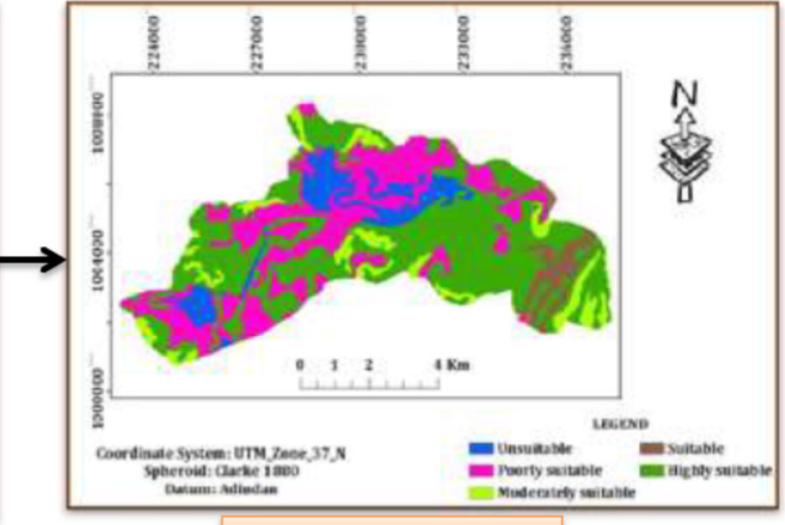

Ranked soil types

Umb_Umbric, Hum_Humic, Lix_Lixisols, Mol_Mollic, Rho-Rhodic, Nit_Nitisols, Cam_Cambisols, Acr_Acrisols

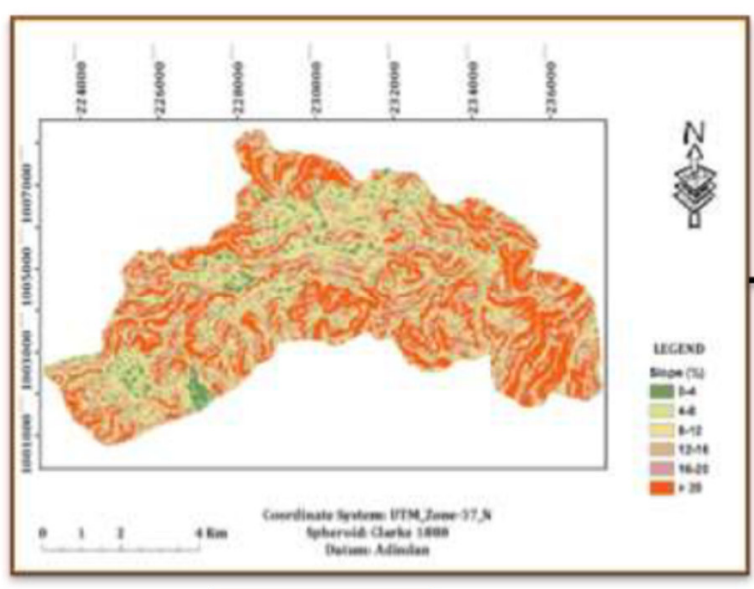

Slope

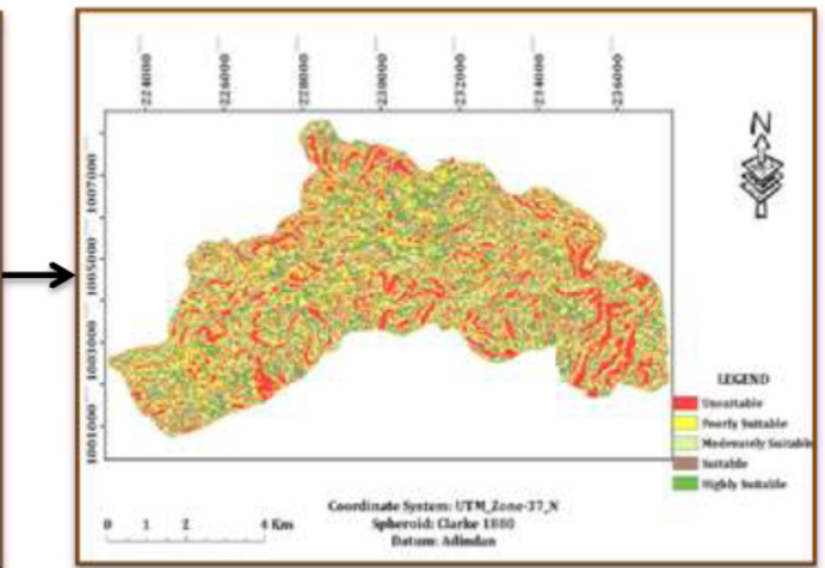

Ranked Slope

Figure 4: Original and reclassified thematic maps 


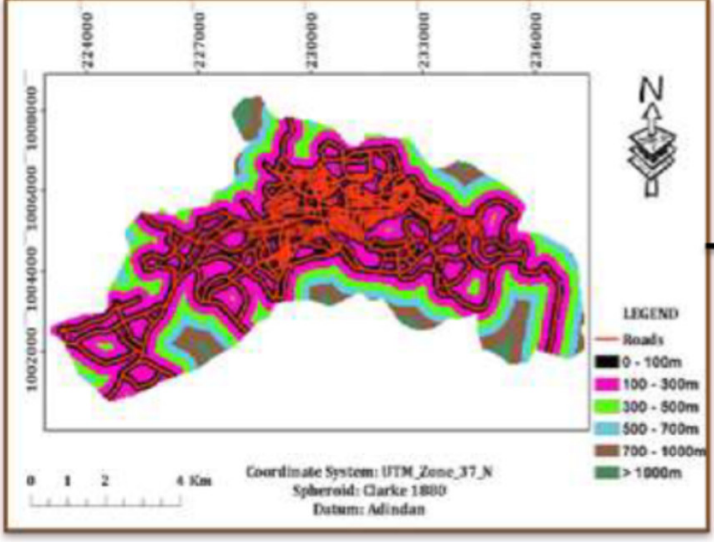

Road network buffer

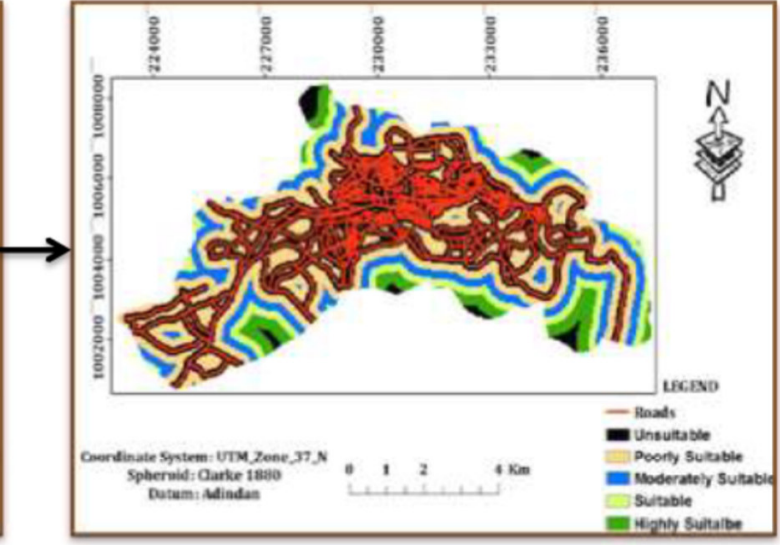

Ranked road network buffer

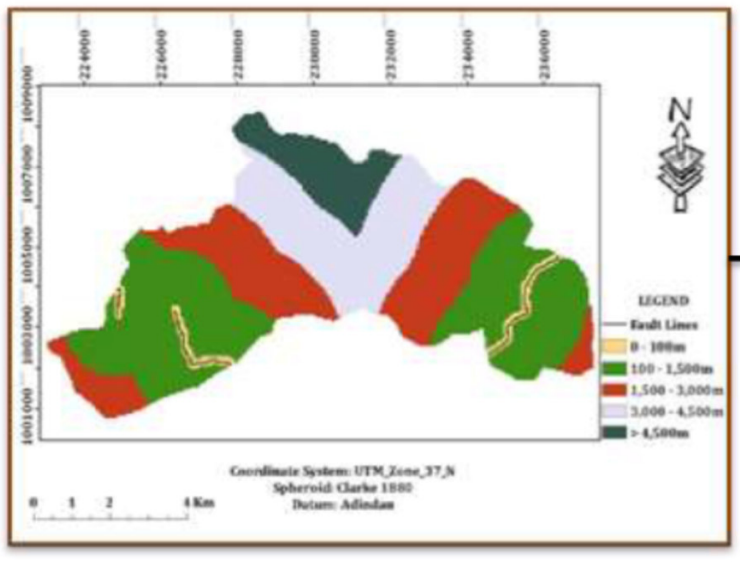

Faults buffer

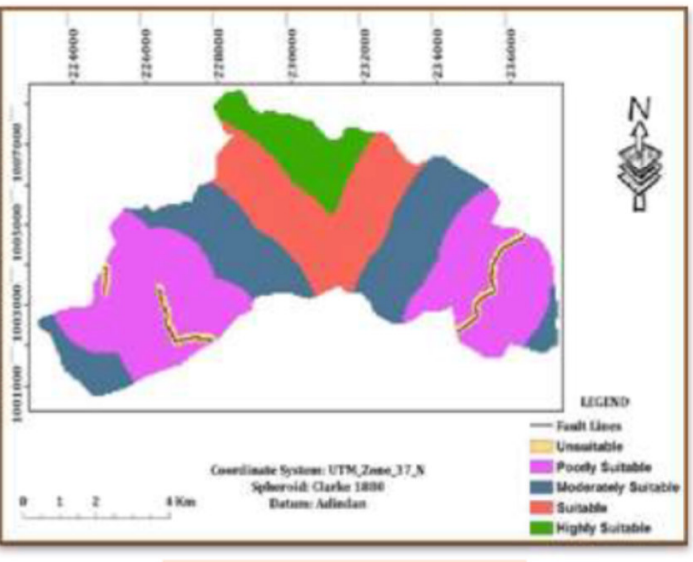

Ranked faults buffer

Figure 5: Original and reclassified thematic maps

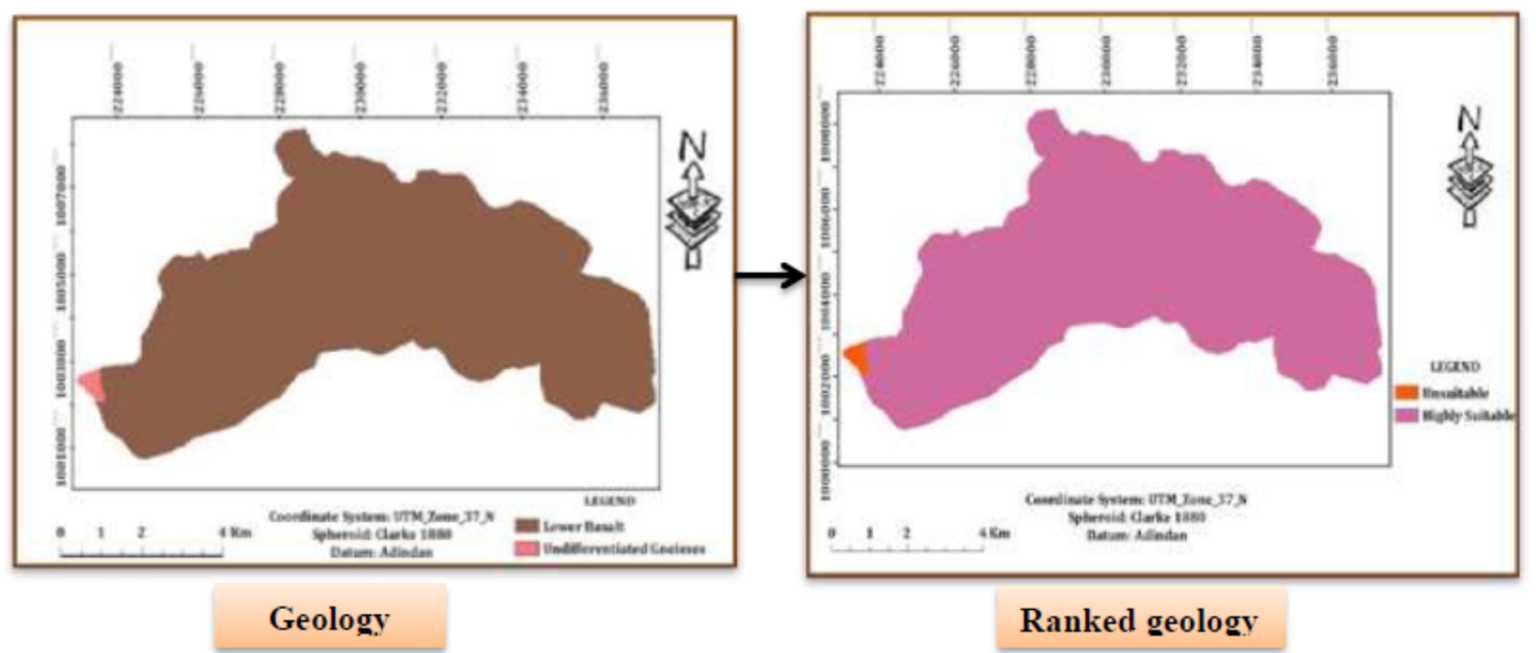

Figure 6: Original and reclassified thematic maps

\section{RESULTS}

Land use/land cover

After classifying the Landsat 8 image of the study area, the shape-file of the built-up area, open land, vegetation 
and the two artificial lakes was merged into other land use/land cover shape-file which was prepared by the municipality. Consequently, fifteen land use/land cover types were identified. After reviewing various literatures on the suitability of those land LU/LC types for municipal solid disposal site selection, the study area was reclassified into five suitability classes with respect to the value of the land and its social effects.

\section{Proximity to built-up areas}

In municipal solid waste disposal site selection, sites farther from built-up, especially from residential areas are more preferable to those sites closer to the built-up areas in order to reduce public nuisance and opposition. In addition, the farthest sites were excluded from the selection process to reduce transportation cost. Accordingly, the study area was classified into five suitability classes: $0-500 \mathrm{~m} \&>2,500 \mathrm{~m}, 500-1000 \mathrm{~m}, 1,000-1,500 \mathrm{~m}, 1,500$ $-2,000 \mathrm{~m}, 2,000-2,500 \mathrm{~m}$.

\section{Proximity to Lakes and Rivers/Streams}

As contaminated runoff generated from the municipal solid waste disposal site could pollute surface water bodies including lakes, rivers and streams, minimum buffer zones of $150 \mathrm{~m}$ for rivers/streams and $250 \mathrm{~m}$ for lakes were created for municipal solid waste site selection and accordingly the study area was classified into five suitability classes. $0-150 \mathrm{~m}, 150-350 \mathrm{~m}, 350-600 \mathrm{~m}, 600-850 \mathrm{~m}$, and $>850 \mathrm{~m}$ for rivers/streams and $0-250 \mathrm{~m}, 250-1,250 \mathrm{~m}$, $1,250-2,250 \mathrm{~m}, 2,250-3,250 \mathrm{~m}$ and $>3,250 \mathrm{~m}$ for lakes.

\section{Soil permeability characteristics}

In order to prevent groundwater pollution, municipal solid waste disposal sites should be located on soils with low permeability and high natural attenuation. With this regard, the study area was categorized into suitability classes.

\section{Slope}

By considering the effect of slope on the possibility of groundwater pollution and construction cost, the study area was classified into five suitability classes: $0-4 \&>20 \%, 4-8 \%, 8-12 \%, 12-16 \%$, and $16-20 \%$.

\section{Proximity to roads}

By considering transportation cost to the disposal site, traffic congestion and the effect of waste transport on public health, the study area was classified into five suitability classes: $0-100 \&>1000 \mathrm{~m}, 100-300 \mathrm{~m}, 300-500 \mathrm{~m}, 500$ $-700 \mathrm{~m}$ and $700-1000 \mathrm{~m}$.

\section{Proximity to faults}

The faults data was digitized from the geological map of the Nekemte area prepared by GSE (2000). The existence of faults adversely affects the integrity of the waste disposal site and could cause groundwater pollution. With this regard, a minimum of $100 \mathrm{~m}$ buffer zone around the faults was created and accordingly the study area was classified into five suitability classes: $0-100 \mathrm{~m}, 100-1,500 \mathrm{~m}, 1,500-3,000 \mathrm{~m}, 3,000-4,500 \mathrm{~m}$, and $>4,500 \mathrm{~m}$.

\section{Geology}

By considering the existence of fractures, the type, and permeability characteristics of the rocks, the study area was classified into two suitability classes.

\section{DISCUSSION}

\section{Municipal Solid Waste Disposal Site Suitability}

The overall suitability analysis revealed that five disposal site suitability classes: unsuitable, poorly suitable, moderately suitable, suitable and highly suitable. However, the area of the highly suitable site was very small. As a result, this suitability class was excluded from the selection process. During the process of this municipal solid waste disposal site selection, built-up areas, surface water bodies, roads, sport fields and recreational areas and riverside green vegetation were excluded due to their social effect and value. While open space/lands in the study area, were considered as highly suitable for municipal solid waste disposal site selection. Sites which are within $150 \mathrm{~m}$ from rivers/streams, $250 \mathrm{~m}$ from lakes, $100 \mathrm{~m}$ from faults, $100 \mathrm{~m}$ and $>1000 \mathrm{~m}$ from roads and with slopes of $0-4 \%$ and $>20 \%$ were excluded from the selection process.

With respect to area, the suitability analysis showed that $48.29 \%$ of the study area was unsuitable and only $4.46 \%$ of it was suitable for municipal solid waste disposal site selection. The remaining $46.34 \%$ of the study areas was moderately suitable, which was again not considered to select candidate disposal sites. 
Table 1:Comparison matrix of the criteria

\begin{tabular}{cccccccccccc}
\hline Factor & LU/LC & Bu & La & Ri & So & SI & Ro & Fa & Ge & Weight & Weight (\%) \\
\hline LU/LC & 1 & 2 & 2 & 3 & 5 & 5 & 5 & 7 & 7 & $\mathbf{0 . 2 7}$ & $\mathbf{2 7}$ \\
Bu & $1 / 2$ & 1 & 1 & 3 & 5 & 3 & 5 & 5 & 7 & $\mathbf{0 . 2 0}$ & $\mathbf{2 0}$ \\
La & $1 / 2$ & 1 & 1 & 3 & 3 & 3 & 3 & 5 & 5 & $\mathbf{0 . 1 7}$ & $\mathbf{1 7}$ \\
$\mathbf{R i}$ & $1 / 3$ & $1 / 3$ & $1 / 3$ & 1 & 3 & 3 & 3 & 5 & 5 & $\mathbf{0 . 1 2}$ & $\mathbf{1 2}$ \\
So & $1 / 5$ & $1 / 5$ & $1 / 3$ & $1 / 3$ & 1 & 1 & 2 & 3 & 3 & $\mathbf{0 . 0 6}$ & $\mathbf{6}$ \\
SI & $1 / 5$ & $1 / 3$ & $1 / 3$ & $1 / 3$ & 2 & 1 & 2 & 3 & 5 & $\mathbf{0 . 0 8}$ & $\mathbf{8}$ \\
Ro & $1 / 5$ & $1 / 5$ & $1 / 3$ & $1 / 3$ & $1 / 2$ & $1 / 2$ & 1 & 3 & 3 & $\mathbf{0 . 0 5}$ & $\mathbf{5}$ \\
Fa & $1 / 7$ & $1 / 5$ & $1 / 5$ & $1 / 5$ & $1 / 3$ & $1 / 3$ & $1 / 3$ & 1 & 3 & $\mathbf{0 . 0 3}$ & $\mathbf{3}$ \\
Ge & $1 / 7$ & $1 / 7$ & $1 / 5$ & $1 / 5$ & $1 / 3$ & $1 / 5$ & $1 / 3$ & $1 / 3$ & 1 & $\mathbf{0 . 0 2}$ & $\mathbf{2}$ \\
Total & $\mathbf{3 . 2 1}$ & $\mathbf{5 . 4 0}$ & $\mathbf{5 . 7 2}$ & $\mathbf{1 1 . 3 9}$ & $\mathbf{2 0 . 1 6}$ & $\mathbf{1 7 . 0 3}$ & $\mathbf{2 1 . 6 6}$ & $\mathbf{3 2 . 3 3}$ & $\mathbf{3 9 . 0 0}$ & $\mathbf{1 . 0 0}$ & $\mathbf{1 0 0}$ \\
\hline
\end{tabular}

Where: LU/LC Land use/Land cover; Bu-Built-up area; La-Lake;Ri-Rivers;

So-Soil; Sl-Slope; Ge-Geology; Fa-Fault lines; and Ro-Road network

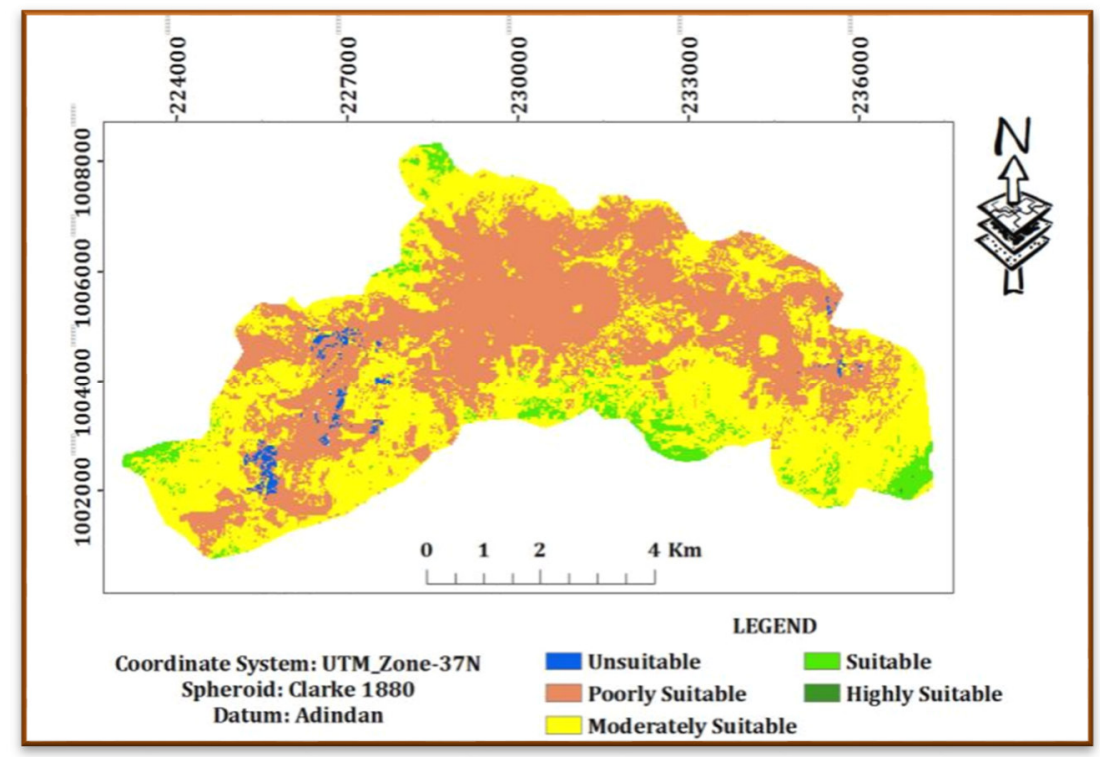

Figure 7: Municipal Solid Waste Disposal Site Suitability Map of the Study area

\section{Candidate Landfill Sites}

With respect to economic advantage, potential disposal sites with areas of less 11 ha were excluded from the selection process. Accordingly, six potential disposal sites were selected, evaluated with respect to their size, their distance from the nearby built-up area and distance from the center of the town and finally ranked and mapped.

With respect to their size, there was one candidate disposal site with an area of 43 ha, which could be considered as highly suitable as it can serve for a long period of time due to its larger capacity than the one with the smallest of 11 ha, which was considered as the poorly suitable. However, with respect to their distance from the center of the town, candidate disposal site six (CDS-6) was the most suitable.

In order to solve such conflicting interests, all the three evaluating criteria were considered simultaneously through Analytic Hierarchy Process (AHP). Weights given to the criteria showed that the size of the candidate disposal sites was more important than the remaining two criteria - distance from center and nearby built-up area.

\section{Table 2: Evaluating criteria weights}

\begin{tabular}{lcc}
\hline \multicolumn{1}{c}{ Criteria } & Weight & Weight (\%) \\
\hline Size of the site & 0.63 & 63 \\
Distance from center & 0.11 & 11 \\
Distance from nearby built-up area & 0.26 & 26 \\
Total & $\mathbf{1}$ & $\mathbf{1 0 0}$ \\
\hline
\end{tabular}

Consistency Ratio: 0.07, which is less than 0.1 
Table 3: Comparison matrices of the candidate disposal sites

Weight of CDS with respect to their size

\begin{tabular}{|c|c|c|c|c|c|c|c|c|}
\hline Area & CDS-1 & CDS-2 & CDS-3 & CDS-4 & CDS-5 & CDS-6 & Weight & Weight (\%) \\
\hline CDS-1 & 1 & 1 & 2 & 3 & 3 & 4 & 0.3 & 30 \\
\hline CDS-2 & 1 & 1 & 1 & 2 & 2 & 3 & 0.22 & 22 \\
\hline CDS-3 & $1 / 2$ & 1 & 1 & 2 & 2 & 2 & 0.19 & 19 \\
\hline CDS-4 & $1 / 3$ & $1 / 2$ & $1 / 2$ & 1 & 1 & 2 & 0.11 & 11 \\
\hline CDS-5 & $1 / 3$ & $1 / 2$ & $1 / 2$ & 1 & 1 & 1 & 0.1 & 10 \\
\hline CDS-6 & $1 / 4$ & $1 / 3$ & $1 / 2$ & $1 / 2$ & 1 & 1 & 0.08 & 8 \\
\hline Total & 3.42 & 4.33 & 5.5 & 9.5 & 10 & 13 & 1 & 100 \\
\hline \multicolumn{9}{|c|}{ Weight of CDS with respect to distance from center } \\
\hline DFC & CDS-1 & CDS-2 & CDS-3 & CDS-4 & CDS-5 & CDS-6 & Weight & Weight (\%) \\
\hline CDS-1 & 1 & $1 / 3$ & 1 & $1 / 3$ & $1 / 3$ & $1 / 4$ & 0.07 & 7 \\
\hline CDS-2 & 3 & 1 & 3 & 1 & 1 & $1 / 2$ & 0.19 & 19 \\
\hline CDS-3 & 1 & $1 / 3$ & 1 & $1 / 2$ & $1 / 2$ & $1 / 4$ & 0.08 & 8 \\
\hline CDS-4 & 3 & 1 & 2 & 1 & 1 & $1 / 2$ & 0.17 & 17 \\
\hline CDS-5 & 3 & 1 & 2 & 1 & 1 & $1 / 2$ & 0.17 & 17 \\
\hline CDS-6 & 4 & 2 & 4 & 2 & 2 & 1 & 0.32 & 32 \\
\hline Total & 15 & 5.67 & 13 & 5.83 & 5.83 & 3 & 1 & 100 \\
\hline \multicolumn{9}{|c|}{ Weight of CDS with respect to DFNB } \\
\hline DFNBU & CDS-1 & CDS-2 & CDS-3 & CDS-4 & CDS-5 & CDS-6 & Weight & Weight (\%) \\
\hline CDS-1 & 1 & 8 & 2 & 3 & 8 & 7 & 0.44 & 44 \\
\hline CDS-2 & $1 / 8$ & 1 & $1 / 4$ & $1 / 3$ & 1 & 1 & 0.06 & 6 \\
\hline CDS-3 & $1 / 2$ & 4 & 1 & 2 & 4 & 3 & 0.23 & 23 \\
\hline CDS-4 & $1 / 3$ & 3 & $1 / 2$ & 1 & 3 & 3 & 0.15 & 15 \\
\hline CDS-5 & $1 / 8$ & 1 & $1 / 4$ & $1 / 3$ & 1 & 1 & 0.06 & 6 \\
\hline CDS-6 & $1 / 7$ & 1 & $1 / 3$ & $1 / 3$ & 1 & 1 & 0.06 & 6 \\
\hline Total & 2.23 & 18 & 4.33 & 7 & 18 & 16 & 1 & 100 \\
\hline
\end{tabular}

Consistency ratio $=.018,0.018$ and 0.024 , all of which are less than 0.1 , which means acceptable judgment.

Where: CDS_candidate disposal site; DFC_distance from center and DFNB_distance from nearby built-up area.

As it can be observed from table 3, CDS-1, CDS-2 and CDS-3 are the first three highly suitable sites with respect to area (size), while the remaining CDS-4, CDS-5 and CDS-6 are the least suitable sites. However, with respect to the distance from center, CDS-6, CDS-2 and CDS-4 \&CDS-5 are the first, $2^{\text {nd }}$ and $3^{\text {rd }}$ suitable sites, whereas CDS-1 and CDS-3 and CDS-1 are the least suitable sites. In terms of their distance with respect to the nearby built-up area, CDS-1, CDS-3 and CDS-4 take the $1^{\text {st }}, 2^{\text {nd }}$ and $3^{\text {rd }}$ rank, respectively. And CDS-2, CDS-5 and CDS-6 each take the $4^{\text {th }}$ rank.

The aggregate weight of the six candidate disposal sites with respect to the evaluating criteria was computed and they were ranked as shown in table 4.

Table 4: Weight and rank of CDS

\begin{tabular}{|c|c|c|c|c|c|c|}
\hline \multirow{2}{*}{ CDS } & Area & DFC & DFNBU & \multirow{2}{*}{$\begin{array}{c}\text { Aggregate } \\
\text { Weight }\end{array}$} & \multirow{2}{*}{ Weight (\%) } & \multirow{2}{*}{ Rank } \\
\hline & 0.63 & 0.11 & 0.26 & & & \\
\hline CDS-1 & $0.63 * 0.30$ & $0.11 * 0.07$ & $0.26 * 0.44$ & 0.31 & 31 & 1 \\
\hline CDS-2 & $0.63 * 0.22$ & $0.11 * 0.19$ & $0.26 * 0.06$ & 0.18 & 18 & 3 \\
\hline CDS-3 & $0.63 * 0.19$ & $0.11 * 0.08$ & $0.26 * 0.23$ & 0.19 & 19 & 2 \\
\hline CDS-4 & $0.63 * 0.11$ & $0.11 * 0.17$ & $0.26 * 0.15$ & 0.13 & 13 & 4 \\
\hline CDS-5 & $0.63 * 0.10$ & $0.11 * 0.17$ & $0.26 * 0.06$ & 0.09 & 9 & 6 \\
\hline CDS-6 & $0.63 * 0.08$ & $0.11 * 0.32$ & $0.26 * 0.06$ & 0.10 & 10 & 5 \\
\hline Total & & & & 1.00 & 100 & \\
\hline
\end{tabular}

Table 4 reveals that CDS-1, CDS-3 and CDS-2 are the $1^{\text {st }}, 2^{\text {nd }}$ and $3^{\text {rd }}$ suitable sites with respect to the area (size), the distance from center and nearby built-up area. CDS-5 is the least suitable candidate disposal site. CDS1, CDS-2, and CDS-5 are found in Burka Jato Sub-town; CDS-3 is located in Sorga Sub-town; CDS-4 is found in Kaso Sub-town and CDS-6 is found in Darge Sub-town. 


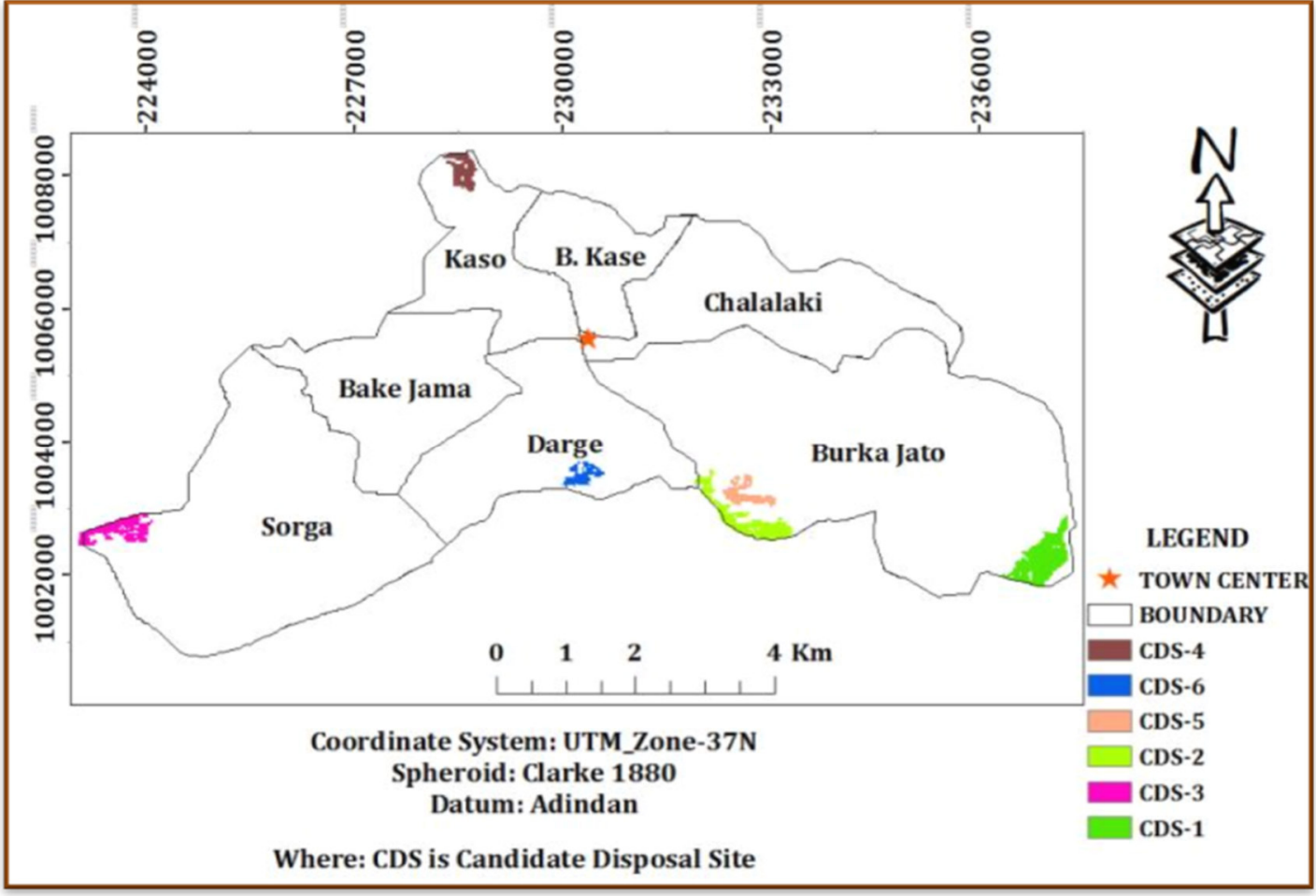

Figure 8: Candidate disposal sites map

\section{CONCLUSION}

This study considered nine criteria - land use/land cover types, distance from the built-up areas, distance from rivers/streams, distance from lakes, soil permeability, slope, distance from road network, distance from fault lines, and geology for suitable municipal solid waste disposal site selection for Nekemte town. About $4.46 \%$ of the study area satisfied the socio-economic and environmental criteria established for the site selection. Hence, it was designated as suitable. Of the suitable sites, six candidate municipal disposal sites with areas of 11 ha and above were evaluated in terms of their size, distance from center and distance from the nearby built-up area. The result of the evaluation showed that candidate disposal 1, which is found in the Burka Jato sub-town is the most suitable site. Candidate disposal sites 3 and 2, which are found in the Sorga and Burka Jato sub-town, respectively are the $2^{\text {nd }}$ and $3^{\text {rd }}$ suitable sites.

\section{REFERENCES}

1. Al-Ansari N (2013) Locating Landfills in Arid Environment Journal of Earth Sciences and Geotechnical Engineering 3: 11-24.

2. Allende R (2009) Waste History in the Gambia. MSc Thesis, University of the Gambia, Sere Kunda.

3. Tchobanoglous G Kreith F (2002) Handbook of Solid Waste Management. McGraw-Hill, New York.

4. Kao JJ Lin H (1996) Multifactor Spatial Analysis for Landfill Siting. Journal of Environmental Engineering, 122: 902-908.

5. Siddiqui MZ, Everett JW, Vieux BE (1996) Landfill Siting Using Geographic Information Systems: A Demonstration. Journal of Environmental Engineering, 122:515-523. http://dx.doi.org/10.1061/(ASCE)0733-9372(1996)122:6(515)

6. Al-Ansari NA, Pusch R, Knutson S (2013) Suggested Landfill Sites for Hazardous Waste in Iraq. Journal of Natural Science 5: 463-477. http://dx.doi.org/10.4236/ns.2013.54060.

7. Al-Ansari NA, Al-Hanbali A, Knutsson S (2012) Locating Solid Waste Landfills in Mafraq City, Jordan. Journal of Advance Science and Engineering Research 2: 40-51.

8. Nas B, Cay T, Iscan F, Berktay A (2008) Selection of MSW Landfill Site for Konya, Turkey Using GIS and Multi-Criteria Evaluation. Environmental Monitoring and Assessment, 160: 491-500. http://dx.doi.org/10.1007/s10661-008-0713-8.

9. Oromia Water Works Design and Supervision Enterprise (2014): Dhidhessa-Dabus Integrated Land Use Planning Project Final Report. Section II: Sectorial Study, Vol. I: Dhidhessa Sub-Basin Soil Survey.

10. Geological Survey of Ethiopia (2000): Geology of the Nekemte Area, Memoir No 14, compiled by Solomon Gerra and Mulugeta Haile-Mariam, , Addis Ababa. 